\title{
PERFORMA PRODUKSI DAN REPRODUKSI SAPI PERAH DI UPTD BPPIP- TSP BUNIKASIH
}

(Production And Reproductive Performance Of Daily Cattle At UPTD BPPIP-TSP Bunikasih)

\author{
Pria Sembada1), Irsan Ramadhan'1), Rizky FR'), Aldi Mugniawan'), \\ M Rifky Ramdani Hendrawan ${ }^{1)}$ \\ 1)Program Studi Teknologi dan Manajemen Ternak, Sekolah Vokasi, Institut Pertanian \\ Bogor, Bogor 16680, Indonesia \\ E-mail : priasembada@apps.ipb.ac.id
}

Diterima 25 Mei 2021/Disetujui 8 Juli 2021

\begin{abstract}
Dairy farms in Indonesia have great potential to develop. However, dairy farming in Indonesia faces various challenges, especially in improving reproductive and production performance. The vital role of the livestock services needs to be strengthened to enhance livestock performance in West Java. This study aimed to identify reproductive and production performance and factors related to performance at BPPIB-TSP Bunikasih. The research was conducted at BPPIB-TSP Bunikasih from January 13 to April 3, 2020, by collecting primary and secondary data, including population data, feeding practices, production (quality and quantity), and reproduction. These data were analyzed descriptively. The results showed that the reproductive and production performance still need to be improved. Some variables have matched the targets, but some variables still need to be improved, i.e., post-partum matching, conception rate, days open, and calving interval. Important factors related to improving performance include feeding (quantity, quality, and ration balance), management, animal health, and other technical aspects. This study underscores the importance of improving these factors to enhance dairy cows' reproductive performance and production in BPPIB-TSP Bunikasih.
\end{abstract}

Key words : performance, reproduction, production, technical aspects 


\section{PENDAHULUAN}

Peternakan sapi perah di Indonesia memiliki potensi besar untuk berkembang dan dikembangkan. Saat ini dominasi peternakan sapi perah masih terpusat di pulau Jawa, yaitu sebesar 99 persen. Karakteristik peternakan sapi perah didominasi oleh peternak skala rakyat dengan kepemilikan hanya sekitar 3 hingga 5 ekor per peternakan (Sembada et al., 2020). Produksi susu nasional saat ini masih belum dapat memenuhi total kebutuhan. Badan Pusat Statistik (2020) melaporkan bahwa produksi susu segar dalam negeri (SSDN) baru mampu mencukupi 22 persen dari total kebutuhan, sehingga sisanya (78 persen) didatangkan dari impor. Melihat hal tersebut, potensi pasar sangat besar dan terbuka untuk dapat didukung oleh produksi dalam negeri.

Untuk mengambil peluang besar tersebut, produktivitas, efisiensi, dan daya saing memainkan peran penting. Peran penting tersebut dapat diindikasikan oleh baiknya performa reproduksi dan produksi sapi perah. Performa reproduksi menjadi penting karena berkaitan erat dengan aspek produksi dan peningkatan efisiensi peternakan secara keseluruhan (Asmara et al., 2016). Produksi susu sapi perah di Jawa Barat secara rata-rata adalah sebesar 12 liter per ekor per hari (Sembada et al., 2016) dan lebih rendah dibandingkan dengan produktivitas sapi perah di negara-negara beriklim sedang yang mencapai 26 liter per ekor per hari (Haile-Mariam et al., 2008).

Peternakan sapi perah di Indonesia secara umum menghadapi berbagai tantangan dalam meningkatkan performa reproduksi dan produksi sapi perah. Tantangan-tantangan tersebut antara lain keterbatasan modal, pengetahuan teknis beternak, kesehatan ternak, ketersediaan pakan dan lainnya (Sembada et al., 2019). Oleh karena itu, perlu adanya upaya yang bertujuan dalam meningkatkan performa.

Balai Perbibitan dan Pengembangan Inseminasi Buatan Ternak Sapi Perah (BPPIB-TSP) Bunikasih merupakan Unit Pelaksana Teknis di bawah Dinas Ketahanan Pangan dan Peternakan Provinsi Jawa Barat. Balai ini memegang peranan penting dalam memberikan pelayanan dan contoh kepada para peternak sapi perah terutama di Propinsi Jawa Barat. Hal ini penting mengingat Jawa Barat merupakan salah satu propinsi sentra produksi sapi perah di Indonesia. Seperti yang dilaporkan oleh BPS (2021) bahwa produksi susu Propinsi Jawa Barat tahun 2019 berkontribusi sebesar 32 persen dari total produksi susu dalam negeri. Apabila peternakan sapi perah di Jawa Barat dapat meningkat performa produksi dan reproduksinya, diharapkan dapat memberikan kontribusi besar terhadap produksi susu nasional.

Penelitian ini penting dilakukan untuk mengidentifikasi profil performa produksi dan reproduksi sapi perah yang ada di lokasi penelitian. Selain itu, faktorfaktor yang berkaitan dengan performa juga penting untuk diidentifikasi sehingga dapat dijadikan dasar untuk upaya perbaikan performa ke depan. 


\section{METODE PENELITIAN}

\section{Waktu dan Lokasi}

Penelitian ini dilakukan selama tiga bulan dari 13 Januari hingga 3 April 2020. Penelitian dilakukan di Balai Perbibitan dan Pengembangan Inseminasi Buatan Ternak Sapi Perah (BPPIB-TSP) Bunikasih yang berlokasi di Kampung Padalengsar, Desa Bunikasih, Kecamatan Warungkondang, Kabupaten Cianjur. BPPIB-TSP Bunikasih berada pada posisi geografis $107^{\circ} 03^{\prime} \mathrm{BT}$ dan $6^{\circ} 50^{\prime} \mathrm{LS}$ dengan ketinggian $\pm 1.000 \mathrm{~m}$ dari permukaan laut. Suhu berada pada kisaran 18 $\sim 25 \stackrel{\circ}{\circ}$ dan kelembaban $85 \%$. Curah hujan $266 \mathrm{~mm} /$ tahun pada saat musim hujan dan $51 \mathrm{~mm} /$ tahun pada musim kemarau (Profil BPPIB-TSP Bunikasih, 2020).

Berdasarkan data dari BPPIP-TSP Bunikasih tahun 2020, lahan yang di kelola BPPIB-TSP Bunikasih seluas 24,04 hektar berada di dalam dua wilayah administratif, yaitu di Desa Bunikasih Kecamatan Warungkondang dan di Desa Padaluyu Kecamatan Cugenang Kabupaten Cianjur. Luas lahan tersebut digunakan untuk bangunan dan fasilitas umum (gedung kantor, perkandangan ternak 18 unit, perumahan pegawai, dan lain-lain) seluas 3,975 hektar (16,53\%), paddock exercise ternak 0,26 hektar (1,08\%), kebun Indigofera 1,52 hektar $(6,33 \%)$, kebun rumput seluas 18,52 hektar $(77,04 \%)$ terdiri dari lahan yang efektif ditanami hijauan pakan ternak (HPT) 5,06 hektar (27,32\% dari luasan kebun rumput), semi efektif 8,98 hektar, dan terdapat 4,525 hektar lahan tidak produktif diantaranya terdapat kebun bambu pada lokasi topografi berbukit dan curam.

\section{Pengumpulan Data dan Peubah yang Diamati}

Profil populasi sapi perah yang ada di lokasi penelitian dilakukan berupa jumlah sapi berdasarkan status fisiologis dan dikonversi menjadi ST (Satuan Ternak). Pengamatan lebih mendalam dilakukan terhadap induk sapi laktasi. Induk sapi laktasi dibedakan menjadi dua yaitu induk laktasi awal dan induk laktasi akhir. Kedua kategori induk laktasi tersebut diamati.

Data primer dikumpulkan dengan cara pengamatan secara langsung berupa pengukuran dan observasi terhadap pemberian pakan dan manajemen pemeliharaan. Selain itu, untuk melengkapi data primer, dilakukan juga pengumpulan data sekunder dari BPPIP-TSP Bunikasih berupa data reproduksi, produksi susu, dan data hasil pengujian cepat kualitas susu.

Beberapa peubah yang diamati untuk melihat performa reproduksi seperti yang dilakukan pada penelitian Jaenudin et al., (2018) dan Rasad (2009) antara lain:

1. Jumlah kawin per kebuntingan (Service Per Conception atau $S / C$ ). Peubah ini dihitung berdasarkan jumlah perkawinan yang telah dilakukan untuk menghasilkan suatu kebuntingan dari setiap individu.

2. Jarak Partus ke IB I (Post-Partum Mating). Peubah ini adalah jarak waktu sejak sapi beranak hingga dikawinkan kembali untuk pertama kalinya setelah beranak. Satuan yang digunakan adalah jumlah hari.

3. Conception rate (CR). Peubah ini merupakan angka persentase sapi betina yang bunting dari inseminasi pertama. Satuan yang digunakan adalah persen. (Fadhil dan Hartono, 2017) 
4. Masa Kosong (Days Open). Peubah ini dihitung dari tanggal beranak hingga tanggal perkawinan terakhir yang menghasilkan kebuntingan. Satuan yang digunakan adalah hari.

5. Selang Beranak (Calving Interval). Peubah ini merupakan jarak waktu antara dua kejadian beranak yang berurutan. Satuan yang digunakan adalah hari.

Sementara, data produksi susu yang dikumpulkan adalah data produksi harian pada pemerahan pagi dan sore untuk kelompok induk laktasi awal dan induk laktasi akhir. Data yang dikumpulkan adalah dari bulan Januari hingga Maret 2020. Untuk data kualitas susu, data didapatkan dari data sekunder yang merupakan hasil uji cepat kualitas susu pada saat penelitian. Data kualitas susu yang dikumpulkan antara lain kadar lemak, solid non-fat, total solid, kadar protein, dan berat jenis.

\section{Analisis Data}

Analisis data yang dilakukan adalah analisis deskriptif. Data pemberian pakan dihitung berdasarkan jumlah pemberian dan dikonversi menjadi bahan kering (BK) sesuai dengan bahan pakan yang diberikan. Data reproduksi dan produksi dianalisis secara deskriptif dengan menghitung secara manual dan ditampilkan dalam bentuk nilai rata-rata. Sedangkan, untuk data kualitas susu dihitung berdasarkan rata-rata dari tiga bulan durasi penelitian dilaksanakan. Pengolahan data dilakukan menggunakan Microsoft Excel 2019.

\section{HASIL DAN PEMBAHASAN}

\section{Profil Populasi Sapi Perah}

Populasi sapi perah di UPTD BPPIP-TSP Bunikasih pada bulan Februari 2020 seperti yang tersaji pada Tabel 1 terlihat didominasi oleh induk laktasi. Meskipun demikian, persentase induk laktasi pada bulan tersebut hanya sekitar 30,1 persen. Persentase cukup besar selanjutnya adalah pada jantan dewasa yang mencapai 24 persen.

Tabel 1 Populasi Sapi Perah di BPPIB-TSP Bunikasih Februari 2020

\begin{tabular}{llrrrr}
\hline No & Status Fisiologis & $\begin{array}{c}\text { Populasi } \\
\text { (ekor) }\end{array}$ & $\begin{array}{c}\text { Nilai } \\
\text { konversi } \\
\text { ST }\end{array}$ & \multicolumn{1}{c}{ ST } & STlah \\
\hline 1 & Pedet & 17 & 0,25 & 4,25 & 2,50 \\
2 & Pedet Lepas Sapih & 27 & 0,25 & 6,75 & 3,90 \\
3 & Dara & 59 & 0,50 & 29,50 & 17,10 \\
4 & Jantan Muda & 18 & 0,50 & 9,00 & 5,20 \\
5 & Induk Laktasi & 52 & 1,00 & 52,00 & 30,10 \\
6 & Induk Kering & 29 & 1,00 & 29,00 & 16,80 \\
7 & Jantan Dewasa & 42 & 1,00 & 42,00 & 24,30 \\
\hline & Jumlah Populasi & 244 & & 172,50 & 100,00 \\
\hline
\end{tabular}


Semakin besar jumlah induk laktasi, akan berpengaruh terhadap efisiensi usaha sapi perah yang dijalankan (Asmara et al., 2016). Namun, demikian peternakan ini adalah balai pemerintah yang fokus aktivitasnya lebih kepada pembibitan dan pengembangan inseminasi buatan.

\section{Pemberian Pakan Sapi Perah}

Secara umum, pemberian pakan sapi induk laktasi berbeda dengan status fisiologi lainnya terutama pada pemberian ampas bir. Pada sapi induk laktasi, pemberian pakan sapi induk laktasi sedikit dibedakan berdasarkan status laktasinya (Tabel 2). Sapi induk laktasi awal diberikan pakan konsentrat dengan kuantitas yang lebih banyak dibandingkan dengan sapi induk laktasi akhir.

Tabel 2 Pemberian Pakan Sapi Perah Laktasi

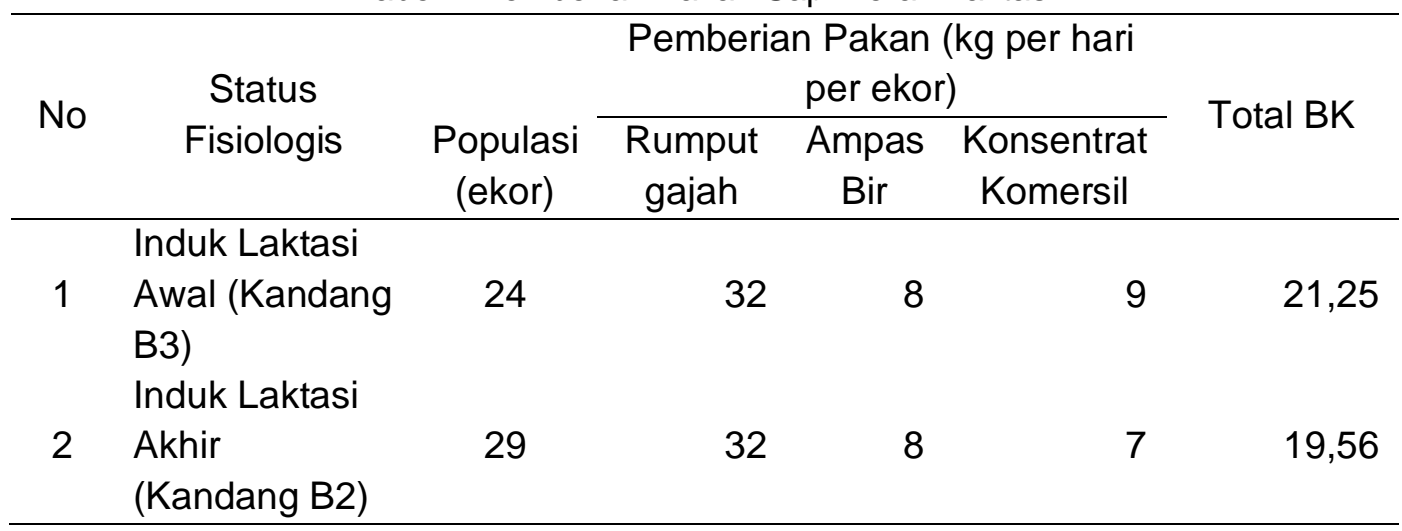

Sumber : UPTD BPPIP-TSP Bunikasih (2020) (data diolah)

Jumlah pemberian hijauan untuk induk laktasi sebesar $32 \mathrm{~kg}$ per ekor per hari dengan frekuensi pemberian dua kali sehari. Selain itu, diberikan juga pakan hijauan tambahan berupa odot, BD, mulato sebanyak $175 \mathrm{~kg}$ per hari untuk semua induk laktasi dengan tujuan melengkapi kekurangan nutrisi pakan yang dikonsumsi. Secara umum, pemberian pakan sapi perah berdasarkan bahan kering hijauan maupun konsentrat sudah sesuai. Jumlah pemberian ini bahkan lebih besar dibandingkan dengan rataan BK yang dilakukan oleh Utomo and Pertiwi (2017) yang hanya kurang dari $10 \mathrm{~kg}$ BK dan Sarah (2015) yang hanya sekitar $15 \mathrm{~kg}$ BK per ekor per hari. Jumlah pemberian ini juga lebih besar dibandingkan dengan standar dari NRC (2001) yaitu sebesar 12,4 kg untuk menghasilkan $10 \mathrm{~kg}$ susu. Namun demikian, imbangan antara hijauan dan konsentrat masih belum ideal dimana persentase hijauan:konsentrat adalah 27:73 untuk induk laktasi awal dan 29:71 untuk induk laktasi akhir. Imbangan yang ideal menurut penelitian Suhendra et al., (2015) adalah 40 persen konsentrat dan 60 persen hijauan. Ketidak seimbangan imbangan dapat berpengaruh pada performa dan kesehatan induk sapi perah.

Pakan konsentrat yang diberikan pada sapi induk laktasi berasal dari konsentrat komersil dari salah satu perusahaan pakan di Indonesia. Sementara, ampas bir merupakan limbah industri pembuatan bir yang menggunakan barley 
dan bahan lain berkadar maltosa tinggi sebagai bahan utama. Ampas bir mengalami proses ferementasi yang dapat meningkatkan kandungan protein dan daya cerna. Bahan pakan ini tidak diproduksi sendiri oleh UPTD BPPIP-TSP Bunikasih namun dibeli dengan harga 1000 per kg.

Tabel 3 Kandungan Nutrisi Konsentrat dan Ampas Bir

\begin{tabular}{lrr}
\hline \multirow{2}{*}{ Nutrien } & \multicolumn{2}{c}{ Jenis Bahan Pakan } \\
\cline { 2 - 3 } & $\begin{array}{c}\text { Konsentrat } \\
\text { Komersil }\end{array}$ & Ampas Bir \\
\hline BK (\%) & 84,71 & 98,71 \\
ABU (\%) & 6,30 & 8,73 \\
PK (\%) & 17,58 & 32,05 \\
SK (\%) & 11,49 & 14,81 \\
LK (\%) & 7,24 & 10,89 \\
BETN (\%) & 1,00 & 33,52 \\
TDN (\%) & 74,46 & 77,24 \\
Ca (\%) & 0,74 & - \\
P (\%) & 0,61 & - \\
Harga Bahan (Rp/Kg) & 4500 & 1000 \\
\hline : UPTD BPPIP-TSP Bunikasih (2020)
\end{tabular}

Hasil analisis yang dilakukan pihak balai menunjukkan bahwa konsentrat komersial memiliki kandungan nutrien yang cukup tinggi terutama protein (Tabel 3). Begitu pula dengan ampas bir yang memiliki kandungan protein bahkan mencapai lebih dari 30 persen. Konsentrat dan ampas bir memiliki peran yang besar dalam meningkatkan produksi susu (Astuti et al., 2012; Pasaribu, 2015; Suhendra et al., 2015).

\section{Performa Reproduksi Sapi Perah}

Performa reproduksi sapi perah dewasa di BPPIB-TSP Bunikasih secara umum lebih rendah dibandingkan dengan yang telah ditargetkan oleh balai tersebut (Tabel 4). Hanya terdapat satu peubah reproduksi yaitu service per conception $(S / C)$ yang melampaui target yang telah ditetapkan. Angka service per conception $(S / C)$ yaitu 1.3 yang berarti lebih baik dibandingkan dengan target $(1,6)$. Angka tersebut juga lebih baik dibandingkan rataan pada umumnya. Rasad (2009) melaporkan bahwa rataan s/c pada peternakan sapi perah yang menjadi anggota salah satu koperasi di Jawa Barat mencapai 1,9-2,0. Penelitian lainnya yang dilaporkan oleh Sulistyowati et al., (2015) didapatkan hasil bahwa rataan s/c pada peternakan sapi perah di Propinsi Bengkulu adalah 1,87-2,0. Keberhasilan s/c di BPPIB-TSP Bunikasih dapat dikaitkan dengan beberapa faktor seperti faktor genetik dan faktor lingkungan yaitu suhu, kelembaban udara, dan manajemen pemeliharaan sapi perah seperti yang dilaporkan oleh Jaenudin et al. (2018) mengenai faktor-faktor yang mempengaruhi efisiensi reproduksi.

Jarak partus ke inseminasi buatan yang berikutnya atau disebut first mating atau first service menjadi salah satu peubah yang perlu diukur. Hal ini karena sapi perah setelah beranak mengalami involusi uterus dengan tujuan mengembalikan 
bentuk uterus menjadi seperti sebelum beranak (Setiadi, 2005). Proses ini umumnya memerlukan waktu sekitar 45 hari. Hasil penelitian menunjukkan bahwa pada peubah ini terdapat perbedaan sekitar 56 hari dibandingkan dengan yang telah ditargetkan. Dengan kata lain, hal ini berarti terjadi keterlambatan terhadap IB selanjutnya setelah partus. Keterlambatan ini dapat berpengaruh terhadap performa reproduksi secara keseluruhan. Faktor-faktor yang mungkin dapat dikaitkan dengan keterlambatan tersebut antara lain faktor kesehatan sapi, manajemen perkawinan, dan deteksi berahi. Meskipun faktor-faktor tersebut masih perlu diobservasi lebih dalam.

Hal yang menarik lainnya adalah performa reproduksi yang dilihat dari peubah conception rate pada IB pertama tergolong cukup rendah (26 persen). Beberapa hal diduga menyebabkan rendahnya conception rate tersebut antara lain nutrisi ternak, kesehatan dan manajemen perkawinan. Seperti yang dilaporkan pada hasil penelitian yang dilakukan oleh Jaenudin et al. (2018) dan Setiadi (2005) yang menyatakan bahwa conception rate dipengaruhi oleh stres panas, nutrisi, kesehatan, manajemen perkawinan, deteksi berahi, dan pengalaman serta keahlian inseminator. Selain itu, Fadhil and Hartono (2017) dalam penelitiannya melaporkan bahwa conception rate juga dipengaruhi oleh pengetahuan beternak dan pemberian pakan dan minum sapi induk.

Tabel 4 Target dan Capaian Penampilan Reproduksi Sapi Perah Dewasa di BPPIB-TSP Bunikasih

\begin{tabular}{clcr}
\hline No & \multicolumn{1}{c}{ Peubah } & Target & Capaian \\
\hline 1 & Service per Conception (S/C) & 1,6 & 1,30 \\
2 & Jarak Partus Ke IB I (hari) & $60-80$ & 136,70 \\
3 & CR oleh IB pertama (\%) & $>80$ & 26,32 \\
4 & Days Open (hari) & 120 & 125,43 \\
5 & Calving Interval (bulan) & 13 & 13,48 \\
\hline
\end{tabular}

Sumber: Sumber: UPTD BPPIP-TSP Bunikasih (2020) (data diolah)

Capaian peubah days open dan calving interval sudah mendekati target yang telah ditetapkan. Days open sendiri hanya selisih lima hari dibandingkan dengan target, sementara calving interval juga memiliki selisih kurang dari sebulan. Beberapa faktor yang dapat dikaitkan dengan capaian dua peubah tersebut antara lain faktor genetika dan faktor lingkungan seperti suhu, kelembaban, dan musim (Bayou et al., 2015). Selain itu, faktor lainnya yang dapat mempengaruhi lamanya days open dan calving interval menurut Reswati et al. (2014) antara lain: lamanya muncul berahi kembali setelah melahirkan, kurangnya pengetahuan peternak dalam mendeteksi estrus setelah melahirkan, dan terjadinya kawin berulang. Days open dan calving interval yang terlalu lama dapat menyebabkan biaya pemeliharaan semakin tinggi dan kesempatan mendapatkan penerimaan dari penjualan pedet dan susu menjadi tertunda (Lake dan Purwantiningsih, 2020). Oleh karena itu, perlu dilakukan upaya untuk meningkatkan performa reproduksi untuk dua peubah tersebut. 


\section{Performa Produksi Sapi Perah}

Hasil penelitian menunjukkan bahwa secara umum terjadi peningkatan produktivitas sapi induk laktasi dari Januari hingga Maret 2020 sebesar 6 persen. Peningkatan ini salah satunya disebabkan oleh meningkatnya produktivitas kelompok induk laktasi awal sebesar 12,5 persen. Meskipun, di sisi lain produktivitas kelompok induk laktasi akhir terlihat cenderung fluktuatif. Hal ini sesuai dengan pendapat Javed et al. (2004) dan Makin (2012) yang menyatakan bahwa panjang laktasi, laktasi ke-berapa serta DIM (days in milk) berpengaruh terhadap produksi susu sapi perah. Produksi susu membentuk kurva sigmoid dimana pada awal laktasi produksi susu rendah kemudian semakin meningkat. Namun, pada bulan ke-3 laktasi (DIM 60-90) terjadi puncak laktasi dan kemudian produksi susu mulai kembali menurun hingga menjelang dikeringkan. Faktor-faktor lain yang diduga dapat berpengaruh terhadap produksi susu antara lain jumlah pakan, jumlah air minum, umur ternak, luas kandang dan interval pemerahan (Pasaribu, 2015).

Tabel 5 Produktivitas induk laktasi selama bulan Januari-Maret 2020

\begin{tabular}{|c|c|c|c|}
\hline $\begin{array}{l}\text { Performa Produksi } \\
\text { Susu }\end{array}$ & $\begin{array}{c}\text { Induk Laktasi } \\
\text { Awal } \\
\text { (Kandang } \\
\text { B3) }\end{array}$ & $\begin{array}{l}\text { Induk Laktasi } \\
\text { Akhir } \\
\text { (Kandang } \\
\text { B2) }\end{array}$ & $\begin{array}{l}\text { Total Induk } \\
\text { Laktasi }\end{array}$ \\
\hline \multicolumn{4}{|l|}{ Januari } \\
\hline Populasi (ekor) & 24,0 & 29,0 & 53,0 \\
\hline $\begin{array}{l}\text { Rataan Produksi } \\
\text { (liter/ekor/hari) }\end{array}$ & 12,0 & 4,2 & 7,7 \\
\hline \multicolumn{4}{|l|}{ Februari } \\
\hline Populasi (ekor) & 24,0 & 28,0 & 52,0 \\
\hline $\begin{array}{l}\text { Rataan Produksi } \\
\text { (liter/ekor/hari) }\end{array}$ & 12,5 & 4,4 & 8,1 \\
\hline \multicolumn{4}{|l|}{ Maret } \\
\hline Populasi (ekor) & 24,0 & 29,0 & 53,0 \\
\hline $\begin{array}{l}\text { Rataan Produksi } \\
\text { (liter/ekor/hari) }\end{array}$ & 13,5 & 3,9 & 8,2 \\
\hline
\end{tabular}

Secara rata-rata, produktivitas sapi perah yang ada di tempat penelitian ini masih berada pada rataan produktivitas sapi perah pada umumnya. Seperti yang dilaporkan oleh Sembada et al. (2016), produktivitas sapi perah secara rata-rata di peternakan-peternakan sapi perah Kabupaten Bandung Barat adalah sebesar 11,9-12,6 liter per ekor per hari. Sementara, produktivitas sapi perah di negaranegara tetangga seperti Vietnam mencapai 18 liter per ekor per hari (Vu et al., 2016). Berdasarkan hal tersebut, perlu dilakukan peningkatan produktivitas sapi perah di tempat penelitian ini. Beberapa faktor yang relevan untuk ditingkatkan 
adala faktor genetik dan faktor lingkungan seperti pemberian pakan (kuantitas dan kualitas), umur ternak, dan interval pemerahan.

Temuan menarik dari penelitian ini adalah performa kualitas susu yang dihasilkan memiliki nilai nutrien yang lebih tinggi (terutama total solid dan kadar lemak, Tabel 6) dibandingkan dengan SNI mengenai kualitas susu. Tingginya total solid diiringi dengan tingginya kadar lemak. Kandungan nutrien tersebut dapat dipengaruhi oleh hijauan pakan. Seperti yang telah dibahas sebelumnya bahwa jenis pakan hijauan yang diberikan tidak hanya rumput gajah tetapi juga rumput odot, Indigofera, rumput gajah Taiwan, dan rumput raja. Tingginya total solid dan kadar lemak dapat disebabkan oleh faktor pakan. Penelitian yang dilakukan oleh Ramadhan et al. (2013) menunjukkan bahwa kadar lemak susu tergantung pada kadar serat kasar yang terkandung dalam pakan dan produksi asam asetat. Penambahan Indigofera berpengaruh terhadap meningkatnya kuantitas dan kualitas susu yang dihasilkan karena tingginya kualitas bahan pakan tersebut meskipun kadar Ca dalam darah dan susu tidak mengalami peningkatan secara signifikan (Nurjanah dan Salman, 2019).

Tabel 6 Hasil Uji Kualitas Susu

\begin{tabular}{|c|c|c|}
\hline Indikator Uji & Hasil & SNI \\
\hline Kadar Lemak (\%) & 4,61 & 3,0 \\
\hline Solid non Fat (\%) & 6,80 & 7,8 \\
\hline Total Solid (\%) & 11,41 & 10,8 \\
\hline Kadar Protein (\%) & 2,50 & 2,8 \\
\hline Berat Jenis $(\mathrm{gr} / \mathrm{ml})$ & 1,023 & 1,027 \\
\hline
\end{tabular}

Sumber : UPTD BPPIB-TSP Bunikasih 2020

Namun demikian, kadar solid non-fat, protein, dan berat jenis masih perlu ditingkatkan. Hasil uji menunjukkan bahwa nilai kandungan-kandungan tersebut masih di bawah dari SNI. Strategi yang dapat dilakukan untuk meningkatkan solid non-fat, protein, dan berat jenis adalah dengan meningkatkan pemberian pakan yang berkualitas (Vu et al., 2016).

\section{Peran Pakan dan Faktor-Faktor Lain dalam Meningkatkan Performa Produksi dan Reproduksi}

Hasil penelitian menunjukkan bahwa performa produksi dan reproduksi di tempat penelitian ini secara umum masih perlu diperbaiki meskipun beberapa peubah menunjukkan sudah sesuai dengan yang telah ditargetkan dan standar yang berlaku. Berdasarkan data yang didapatkan, perbaikan yang perlu dilakukan adalah terkait aspek pakan. Hasil observasi di lapang menunjukkan bahwa pakan yang diberikan masih perlu ditingkatkan terutama dari kuantitas hijauan dan imbangan bahan kering antara konsentrat dan hijauan. Penambahan vitamin dan mineral juga diperlukan untuk meningkatkan performa. Seperti yang dilaporkan oleh Astuti et al. (2012) dan Hendrawan et al. (2019), feed suplement memainkan peran penting dalam meningkatnya performa baik produksi maupun reproduksi.

Perbaikan pakan baik dari segi kuantitas, kualitas, dan imbangan tidak hanya berpengaruh pada performa produksi, tetapi juga performa reproduksi. Penelitian 
yang dilakukan oleh menunjukkan bahwa pakan hijauan dan konsentrat yang sesuai dapat meningkatkan performa (Pasaribu, 2015; Sembada et al., 2016; West, 2003). Upaya perbaikan yang dapat dilakukan pada balai ini antara lain perbaikan kualitas dan kuantitas pakan, imbangan pakan konsentrat dan hijauan, serta penambahan feed supplement.

Selain berkaitan dengan pakan, upaya perbaikan lainnya juga perlu dilakukan. Namun, karena kurangnya observasi dan data-data lain mengenai aspek lain maka faktor-faktor lain yang berpengaruh terhadap performa produksi dan reproduksi belum dapat disarankan lebih lanjut. Penelitian selanjutnya perlu dilakukan untuk melihat lebih detail pengaruh faktor-faktor teknis lainnya dalam meningkatkan performa produksi dan reproduksi di tempat penelitian ini. Seperti yang telah dilaporkan oleh Fadhil and Hartono (2017); Pasaribu (2015) danVu et al. (2016) bahwa ada beberapa faktor penting yang dapat mempengaruhi performa, antara lain faktor genetika dan faktor lingkungan serta faktor manajemen.

\section{SIMPULAN}

Berdasarkan hasil penelitian dapat disimpulkan bahwa performa reproduksi dan produksi sapi perah di UPTD BPPIB-TSP Bunikasih untuk beberapa peubah sudah sesuai dengan yang ditargetkan, namun demikian masih terdapat pula peubah-peubah lainnya yang perlu ditingkatkan. Penelitian ini juga masih menemukan beberapa peubah performa reproduksi yang belum sesuai dengan target yang telah ditetapkan seperti jarak partus ke IB I, conception rate, days open dan calving interval. Selain itu, performa produksi (baik kualitas maupun kuantitas) susu sapi perah masih terdapat beberapa indikator yang di bawah standar. Kondisi tersebut dapat diperbaiki dengan meningkatkan faktor-faktor yang berpengaruh terhadap performa, seperti faktor genetika, dan faktor lingkungan. Faktor lingkungan dapat diperbaiki dengan cara manajemen pemberian pakan (kuantitas dan kualitas) yang baik, manajemen pemeliharaan, kesehatan ternak, dan aspek teknis lainnya. Perbaikan-perbaikan tersebut diharapkan dapat memainkan peran penting dalam meningkatkan performa produksi dan reproduksi sapi perah secara keseluruhan di Balai tersebut.

\section{UCAPAN TERIMA KASIH}

Penulis menyampaikan terima kasih kepada pihak UPTD BPPIB-TSP Bunikasih dan Dinas Ketahanan Pangan dan Peternakan Provinsi Jawa Barat yang telah mengizinkan dan membantu proses pengumpulan data pada penelitian ini.

\section{DAFTAR PUSTAKA}


Asmara, A., Purnamadewi, Y.L., Lubis, D., 2016. Keragaan Produksi Susu dan Efisiensi Usaha Peternakan Sapi Perah Rakyat di Indonesia. J. Manaj. dan Agribisnis 13, 14-25. https://doi.org/10.17358/JMA.13.1.14

Astuti, A., Agus, A., Budi, S.P.S., 2012. Pengaruh Penggunaan High Quality Feed Supplement terhadap Konsumsi dan Kecernaan Nutrien Sapi Perah Awal Laktasi (The Effect of High Quality Feed Supplement Addition on the Nutrient Consumption and Digestibility of Early Lactating Dairy Cow). Bul. Peternak. 33, 81. https://doi.org/10.21059/buletinpeternak.v33i2.120

Badan Pusat Statistik, 2020. Produksi Susu Segar menurut Provinsi 2009-2019. [https://www.bps.go.id/linkTableDinamis/view/id/1083]

Bayou, E., Haile, A., Gizaw, S., Mekasha, Y., 2015. Evaluation of non-genetic factors affecting calf growth, reproductive performance and milk yield of traditionally managed Sheko cattle in southwest Ethiopia. SpringerPlus 4, 568. https://doi.org/10.1186/s40064-015-1340-9

Direktorat Jenderal Peternakan dan Kesehatan Hewan, 2020. Statistik Peternakan dan Kesehatan Hewan 2020. Kementerian Pertanian, Jakarta.

Fadhil, M., Hartono, M., 2017. Faktor-Faktor yang Memengaruhi Conception Rate Sapi Perah dada Peternakan Rakyat di Provinsi Lampung 1, 7.

Haile-Mariam, M., Carrick, M.J., Goddard, M.E., 2008. Genotype by Environment Interaction for Fertility, Survival, and Milk Production Traits in Australian Dairy Cattle. J. Dairy Sci. 91, 4840-4853. https://doi.org/10.3168/jds.20081084

Hendrawan, V.F., Firmawati, A., Wulansari, D., Oktanela, Y., Agustina, G.C., 2019. Pemberian Vitamin Sebagai Penanganan Gangguan Reproduksi Sapi Kelompok Ternak Desa Babakan, Kecamatan Karangploso, Kabupaten Malang. J. Nutr. Ternak Trop. 2, 63-69. https://doi.org/10.21776/ub.jnt.2019.002.01.7

Jaenudin, D., Amin, A.A., Setiadi, M.A., Sumarno, H., Rahayu, S., 2018. Hubungan Temperatur, Kelembaban, dan Manajemen Pemeliharaan terhadap Efisiensi Reproduksi Sapi Perah di Kabupaten Bogor. Acta Vet. Indones. 6, 16-23. https://doi.org/10.29244/avi.6.1.16-23

Javed, K., Afzal, M., Sattar, A., Mirza, R.H., 2004. Environmental Factors Affecting Milk Yield in Friesian Cows in Punjab, Pakistan 4.

Lake, H., Purwantiningsih, T.I., 2020. Performans Reproduksi Sapi Perah di Peternakan Sapi Fries Holland (FH) Novisiat Claretian Benlutu. JAS 5, 2527. https://doi.org/10.32938/ja.v5i2.889

Makin, M., 2012. Performa Sifat-Sifat Produksi Susu dan Reproduksi Sapi Perah Fries Holland Di Jawa Barat 12, 6.

NRC, 2001. 7th Revised Edition, Subcommittee on Dairy Cattle Nutrition, Committee on Animal Nutrition, Board on Agriculture and Natural Resources, National Research Council, National Academy Press, Washington, D.C.

Nurjanah, L.T., Salman, L.B., 2019. Pengaruh Pemberian Indigofera zollingeriana, Mineral Zinc dan Selenium terhadap Kadar Kalsium Darah dan Susu Sapi Perah 9. 
Pasaribu, A., 2015. Analisis Faktor-Faktor Yang Mempengaruhi Produksi Susu Sapi Perah Di Kabupaten Karo Provinsi Sumatera Utara 8.

Ramadhan, B.G., Suprayogi, T.H., Sustiyah, A., 2013. Tampilan produksi dan kadar lemak susu kambing ettawa akibat pemberian pakan dengan imbangan hijauan dan konsentrat yang berbeda. J. Anim. Agric. 2(1): 353361.

Rasad, S.D., 2009. Evaluasi Penampilan Reproduksi Sapi Perah (Studi Kasus Di Perusahaan Peternakan Sapi Perah KUD Sinarjaya). J. Agripet 9, 43-49. https://doi.org/10.17969/agripet.v9i1.621

Reswati, R., Jaswandi, J., Nurdin, E., 2014. Performa Reproduksi Sapi Perah di Sumatera Barat. J. Peternak. Indones. Indones. J. Anim. Sci. 16, 157. https://doi.org/10.25077/jpi.16.3.157-165.2014

Sarah, S., 2015. Kecernaan Protein Ransum dan Kandungan Protein Susu Sapi Perah Akibat Pemberian Imbangan Hijauan dan Konsentrat Ransum yang Berbeda 5.

Sembada, P., Duteurtre, G., Moulin, C.-H., 2020. Livestock policy in Indonesia: Case of the dairy subsector. Livest. Policy 11. https://doi.org/DOI: 10.19182/agritrop/00143

Sembada, P., Duteurtre, G., Moulin, C.-H., 2019. The essential role of farm capital in the sustainability of smallholder farms in West Java (Indonesia). Cah. Agric. 28, 15. https://doi.org/10.1051/cagri/2019016

Sembada, P., Duteurtre, G., Purwanto, B.P., Suryahadi, 2016. Improved milk production performance of smallholder farms in West Java (Indonesia). Trop. Anim. Health Prod. 48, 793-799. https://doi.org/10.1007/s11250016-1029-2

Setiadi, M.A., 2005. The role of reproductive health management on dairy and beef cattle farming system. J. Agr and Rur Dev in the Tropics and Subtropics 88:7-12.

Suhendra, D., T. Anggiati, G., Sarah, S., F. Nasrullah, A., Thimoty, A., W. C. Utama, D., 2015. Tampilan kualitas susu sapi perah akibat imbangan konsentrat dan hijauan yang berbeda. J. Ilmu-IImu Peternak. 25, 42-46. https://doi.org/10.21776/ub.jiip.2015.025.01.06

Sulistyowati, E., Kuswadi, E., Sutarno, L., Tampubolon, G., 2015. Penampilan Reproduksi Sapi Perah FH (Friesh Holland) dan Pertumbuhan Pedetnya pada Umur 1 - 3 bulan (Studi Kasus di Desa Air Duku dan Desa Air Putih Kali Bandung, Selupu Rejang, Rejang Lebong, Bengkulu). J. Sain Peternak. Indones. 4, 21-26. https://doi.org/10.31186/jspi.id.4.1.21-26

Utomo, B., Pertiwi, M.D., 2017. Tampilan Produksi Susu Sapi Perah yang Mendapat Perbaikan Manajeman Pemeliharaan. Caraka Tani J. Sustain. Agric. 25, 21. https://doi.org/10.20961/carakatani.v25i1.15528

Vu, N.H., Lambertz, C., Gauly, M., 2016. Factors Influencing Milk Yield, Quality and Revenue of Dairy Farms in Southern Vietnam. Asian J. Anim. Sci. 10, 290-299. https://doi.org/10.3923/ajas.2016.290.299

West, J.W., 2003. Effects of Heat-Stress on Production in Dairy Cattle. J. Dairy Sci. 86, 2131-2144. https://doi.org/10.3168/jds.S0022-0302(03)73803-X 
